\title{
Geological mapping and mineral prospectivity using remote sensing and GIS in parts of Hamissana, Northeast Sudan
}

\author{
Mohamed Taha AIMakki Mohamed ${ }^{1} \cdot$ Latifa Shaheen Al-Naimi $^{2} \cdot$ Tochukwu Innocent Mgbeojedo $^{3}$ (1) . $^{\circ}$ \\ Chidiebere Charles Agoha ${ }^{4}$
}

Received: 19 November 2020 / Accepted: 8 February 2021 / Published online: 6 March 2021

(c) The Author(s) 2021

\begin{abstract}
In recent years, various geological activities and different mineral prospecting and exploration programs have been intensified along the Red Sea hills in order to elucidate the geological maps and to evaluate the mineral potentials. This study is therefore aimed at testing the viability of using remote sensing and geographic information system (GIS) techniques for geological mapping and prospecting for gold mineralization in the area. The study area is located in northeast Sudan and covers an area of about $1379 \mathrm{~km}^{2}$. Different digital image processing techniques were applied to Landsat 8 Operational Land Imager image in order to increase the discrimination between various lithological units and to delineate wall rock alteration which represents target zones for gold mineralization. Image sharpening was performed to enhance the spatial resolution of the images for more detailed information. Contrast stretching was applied after the various digital processing procedures to produce more interpretable images. The principal component analysis transformations yielded saturated images and resulted in more interpretable images than the original data. Several ratio images were prepared, combined together and displayed in RGB color composite ratio images. This process revealed the existence of alteration zones in the study area. These zones extend from the northeast to the southwest in the acid meta-volcanic and silica barite rocks. The enhanced satellite images were implemented in the GIS environment to facilitate the final production of the geological map at scale 1:400,000. X-ray fluorescence analyses prove that selected samples taken from the wall rock alteration zones are gold-bearing.
\end{abstract}

Keywords Geographic information system $\cdot$ Remote sensing $\cdot$ Digital image $\cdot$ Landsat $\cdot$ X-ray fluorescence $\cdot$ Spatial resolution

\section{Introduction}

Remote sensing and GIS techniques have been used for geologic interpretations with resounding success. Remote sensing techniques are generally employed because they provide a cost-effective approach resulting from their ability to access difficult terrains and landforms (such as some

Tochukwu Innocent Mgbeojedo

toomgbeojedo@gmail.com

1 Department of Geology, University of Khartoum, Khartoum, Sudan

2 Department of Chemistry and Earth Sciences, Qatar University, Doha, Qatar

3 Geotechnical Department, Arab Center for Engineering Studies, Doha, Qatar

4 Department of Geology, Federal University of Technology, PMB 1526, Owerri, Nigeria mountains and forest terrains) and data collection can be done rapidly at frequent intervals on a large scale. This thus opened a new era in the mapping of lithologies and alteration zones. Previously, geological maps were developed from field observations derived from the conventional ground survey studies. The plotting of these maps and extrapolation of details were quite rigorous, leading to some unavoidable errors and inaccuracies. The advent of remote sensing and GIS operations has resulted in continuous procedural changes in mapping activities. Now remote sensing techniques play an important role in mapping programs (Farina et al. 2005). Remote sensing is the science of acquiring, processing and interpreting images and related data, acquired from aircraft and satellites that record the interaction between matter and electromagnetic energy (Sabins 1997).

Using data acquired from remote sensing, geologists have focussed on global experiences in several fields of earth science such as environmental, mineral ore and 
hydrocarbon exploration (Aminzadeh and Samani 2006; Elsayed Zeinelabdein and Albiely 2008; Elsayed and El Nadi 2014; Omer and Elsayed Zeinelabdein 2018; Petrovic et al. 2012). The mapping of hydrothermal alteration is based on the examination of the spectral signatures of the mineral veins. It is now known that certain minerals associated with hydrothermal alterations have unique spectral features that allow them to be remotely identified and detected (Modabberi et al. 2017). Lithological mapping and the recognition of hydrothermally altered minerals through the application of remotely sensed data have given encouraging results in the exploration of gold, magnetite and other ore deposits (Amer et al. 2012; Azizi et al. 2010; Rajendran et al. 2012 Van Ruitenbeek et al. 2012).

Remote sensing provides a great merit of synoptic view that is unachievable with most other geophysical prospecting methods. There is also the advantage associated with giving a regional and integrated perspective of the relationships among various land features.

Nowadays, multispectral and high-resolution data are available with digital image processing techniques with advanced capabilities. These have further enlarged the potential of remote sensing in delineating geological structures and lithologies by generating enhanced and interpretable images with a better accuracy level (Drury 1987). The existing multispectral satellite systems are designed and programmed to study natural resources with special focus on vegetative cover, lithology and mineral/ore exploration (Crippen and Blom 2001; Yousif and Shedid 1999; Abrams 1984).

Several applications of remote sensing in geological studies involve delineating structures/structural features, mineral resource exploration rock and soil type discrimination. (Kruse and Dietz 1991). The launch of Landsat Thematic Mapper (TM) in 1982 gave earth scientists access to better spatial (30 m) and spectral resolution (Abrams 1984), compared to the multispectral scanner (MSS) used, for detailed geological studies (Podwysocki et al. 1983). The Landsat TM and ETM+data have been used in various geological surveys for lithological discrimination, lineaments and mineral mapping by using hyper-spectral laboratory (Abrams 1984). Multispectral remote sensing is essential in lithological mapping and zones of alteration, especially in regions of exposed bedrock and bedrock surfaces.

Landsat imagery has been employed for geological purposes by several authors including Elsayed Zeinelabdein and El Nadi (2014); Pournamdary et al. (2014); Safari et al. (2017); Pour and Hashim (2015).

Studies conducted in Southwest USA and elsewhere (Prost 1980; Rowan and Kahle 1982; Podwysocki et al. 1983; Abrams 1984) confirmed that the use of the ratio of TM bands 5 and 7 could make areas of hydrothermal alterations distinguishable.
Other studies utilized band ratioing method to delineate alteration zones around eastern Red Sea Hills (Elsayed Zeinelabdein and Albiely 2008), while lithological mapping was accomplished through image processing techniques in North Sudan (Ali et al. 2012). Remote sensing, GIS and geochemical techniques were used in prospecting for gold mineralization in North Kordofan, Sudan, with results revealing favourable hydrothermal mineral alteration signals, and the presence of auriferous host rocks (Elsayed Zeinelabdein et al. 2020).

These studies reveal that the spectral characteristics of TM bands make them well suited for lithological mapping.

\section{Location, accessibility and geography}

The area studied is in the west of Hamissana, Wadi Edom, which is located in the northwestern flanks of the Red Sea Hills bounded between latitudes $20^{\circ} 22^{\circ} \mathrm{N}$ and $20^{\circ} 50^{\circ} \mathrm{N}$ and longitudes $34^{\circ} 00^{\circ} \mathrm{E}$ and $34^{\circ} 45^{\circ} \mathrm{E}$. The total area studied is approximately 1379 square kilometres (Fig. 1). It forms a part of the Gabgaba terrain that is known to be created among the other four terrains of Northeast Sudan (Tokar, Heya, Gebeit and Gerf) during the Pan-African event (950-500 Ma) due to subduction-related processes and collisional tectonics sutured together by dismembered-ophiolite belts and major shear zones.

\section{Topography and drainage system}

The study area (Wadi Eldoum) lies in the northern part of the Red Sea hills topographic terrain, which generally ranges in height between 500 and $1500 \mathrm{~m}$ above sea level with some isolated peaks that reach up to $2000 \mathrm{~m}$.

The drainage system of the area is irregular, having dendritic pattern (Fig. 2), and seems to be structurally controlled by shear zone, as well as faults, major joint and zones of weakness such as foliations. It is represented by many Wadies and Khors (seasonally intermittent streams). They have many tributaries which come from hills and high relief areas.

\section{Climate and vegetation}

The prevailing climate is the semi-desert type, with very hot and dry summer (March-October), during which day time temperatures can reach up to $46{ }^{\circ} \mathrm{C}$. Winter season is from November to February when day temperature averages $25{ }^{\circ} \mathrm{C}$.

The rainy season in the Red Sea Hills's inland is usually between July and September. The annual rainfall of the whole region is between 100 and $190 \mathrm{~mm}$, Evaporation rate is very high and runoff is rapid. Geological field investigations are best undertaken during the winter season. 


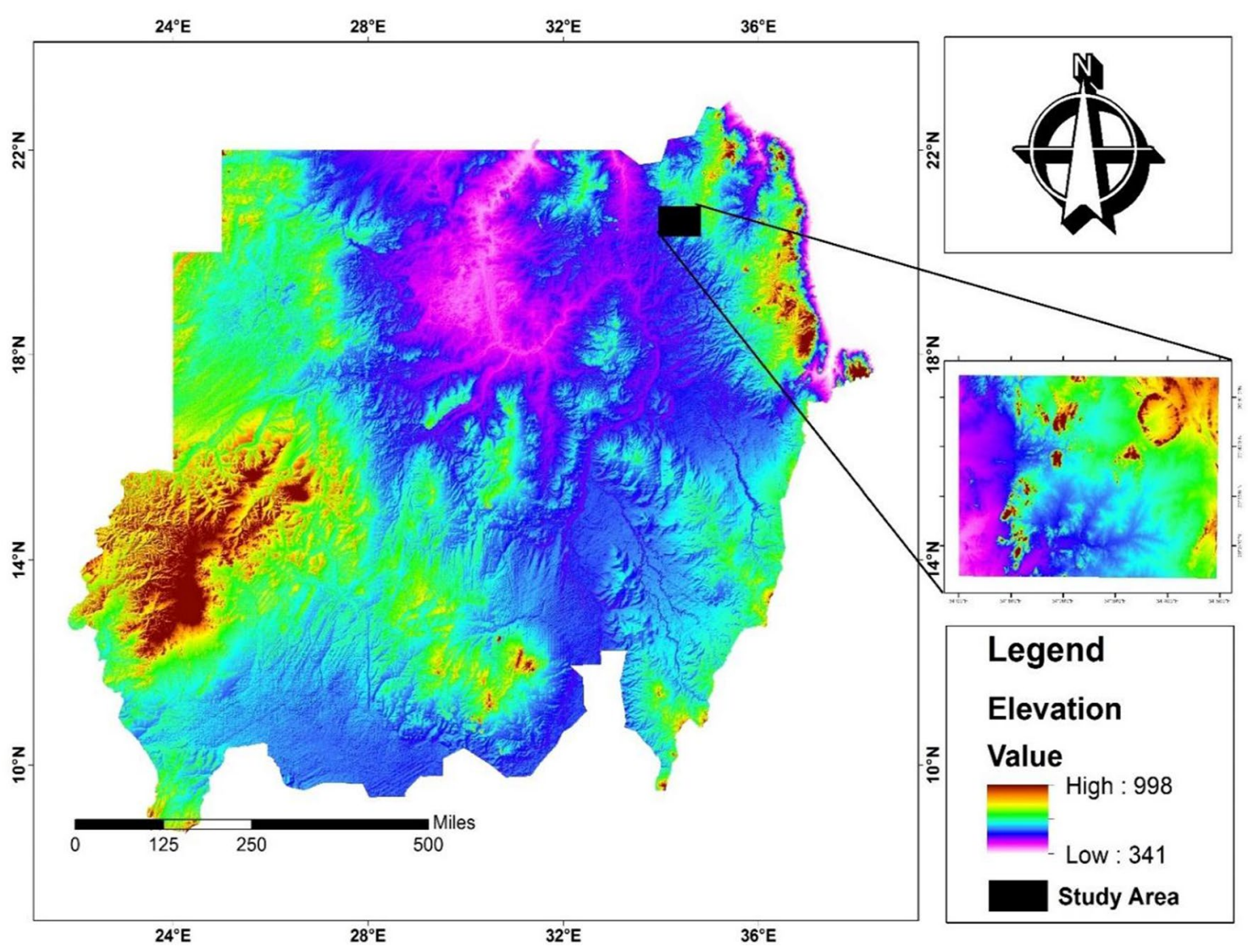

Fig. 1 Location map of the study area

Fig. 2 Drainage and digital elevation map (DEM) of the study area

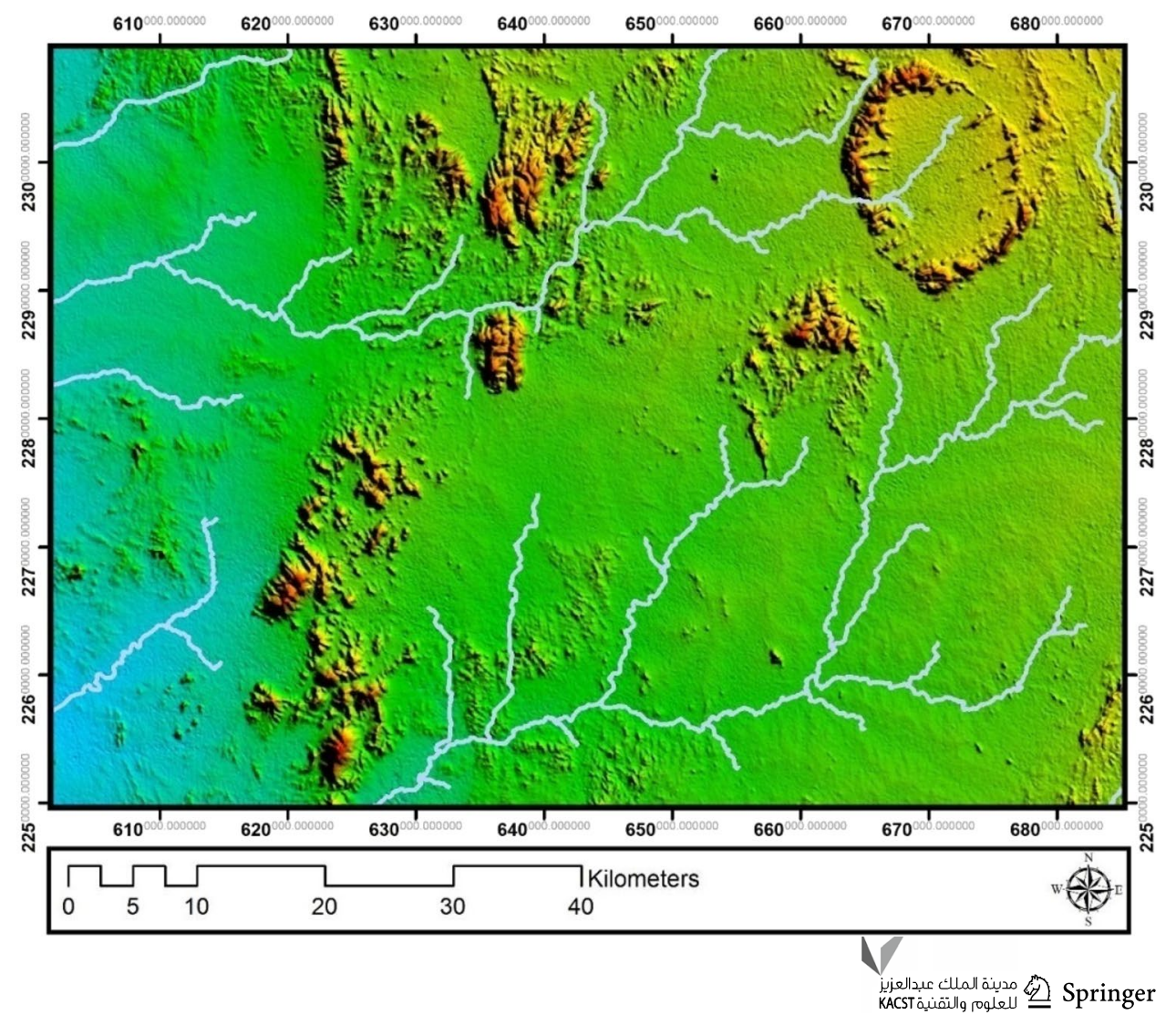


Vegetation is poor and scarce. Bushes and small trees such as Acacia Nilotica, Acacia Etabacia and Xerophytes are confined to the seasonal water courses and some of the sandy plains. Short-lived grass flourishes following the occasional rains on the hill sides and in the plains.

\section{Materials and method}

Different data, materials and methods of data processing have been utilized in the study, and they are illustrated as follows.

Operational land imager (OLI) and thermal infrared sensor (TIRS), Landsat-8 (path 173/Raw 46) acquired on April 30, 2015, were downloaded from the United States Geological Survey (USGS) in a digital format with 16-bit pixel values characteristics. It contains 11 bands. Nine bands with OLI (from band 2 to band 9) were carried in order to define the main lithological units, major structural elements, drainage pattern and to delineate the zones of gold mineralization. Digital Terrain Model (DTM, 90 m resolution) of the area was obtained to enhance the interpretation process and to delineate the drainage system and lineaments. Digital image processing was carried out using the ERDAS IMAGINE ${ }^{\circledR}$ version 14.00 build 350 , while ArcGIS 10.3 was used for data integration and geological mapping.

Visual interpretation of digitally enhanced images was done; different data types were integrated with the ERDAS IMAGINE $^{\circledR}$ environment and then with the geographic information system (ArcGIS 10.3), in order to generate the final geological map and delineate zone of mineralization.

Thirty-six chip samples were collected from quartz veins and mylonitic rocks. Other rock types were collected for geochemical investigation and analyzed using the XRF method. Twenty-five rock hand specimens were collected for thin and polish sectioning of representative samples for petrographic work (using an optical microscope). This is in addition to 52 rock samples collected which represent different selected localities for petrographic interpretation.

Collections of ground control points, rock sampling and structural elements were recorded by GPS receiver during these geo-traverses.

\section{Digital image processing}

This is the manipulation of digital data by computer programs in order to improve the appearance of an image (Gibson 2000). The data used in digital image processing of the present study are the Operational Land Imager (OLI) and the Thermal Infrared Sensor (TIRS). The spatial resolution of OLI multispectral bands is $30 \mathrm{~m}$, the panchromatic band is $15 \mathrm{~m}$, and the thermal band is $100 \mathrm{~m}$. The thermal infrared band has not been used because of its coarse spatial resolution. The software ERDAS IMAGINE is a revolutionary image processing system used in processing the abovementioned satellite data to enhance the quality of their raw digital data and produce images suitable for geological interpretation.

Image interpretation entails distinguishing features based mainly on tonal and textural variations. The following digital image processing techniques outlined below were used.

\section{Image preparation}

The image preparation for the present study included the following steps:

\section{Image subseting}

Using ERDAS IMAGINE ${ }^{\circledR}$ software, spatial subseting was performed on the raw digital images including band 2, 3, 4, 5, 6 and 7 in order to spatially resize the image to the following coordinates: longitude $34^{\circ} 00^{\prime} \mathrm{E}-34^{\circ} 45^{\prime} \mathrm{E}$ and latitude $20^{\circ} 22^{\prime} \mathrm{N}-20^{\circ} 50^{\prime} \mathrm{N}$. This subset covers the study area and helped in tracing major structural elements over a wider regional area.

\section{Resolution enhancement}

The resolution of an image refers to the possible detail reflected by the imagery. This could be in the form of spatial resolution, spectral resolution and temporal resolution. In this study, image sharpening was used to automatically merge the low-resolution multispectral band with the highresolution greyscale band (with resampling to the high-resolution pixel size).

\section{Contrast stretching}

Contrast stretching modifies the grayscale to produce a more interpretable image (Sabins 2000). The number of actually recorded intensity levels in the scene is rather low, and the full dynamic range of the digital image (256 levels) is not fully utilized. It is worth mentioning that contrast stretching was applied in this study after various digital processing procedures to enhance the resulting image, and was not applied as a separate enhancement process. This process basically increases the spatial frequency of the imagery by enhancing such high-frequency features like lineaments.

\section{Principal component analysis (PCA)}

Principal component analysis is often called PCA, or Karhunen-Loeve analysis. Principal components analysis is a change detection technique that converts a set of observations of possibly correlated variables into a set of values of 
linearly uncorrelated variables, called principal components (El Zalaky et al. 2018). The transformation of the raw data using PCA can result in new principal component images that are more interpretable than the original data (Jensen 1996). The PCA is used to compress the information content of a number of bands of imagery or to reduce the dimensionality from a number of bands in two or three PCs (Jensen 1996). In continuation, PCA is extensively applied in remote sensing to determine alterations in rocks and vegetation in a given area. It is also used to reduce the redundancy of information in highly correlated image set.

The flowchart diagram of the adopted methodology for preparation of the geological map of the study area and map of gold mineralization zones is shown in Fig. 3.

\section{Results and discussion}

\section{Color composite images}

Different color composites were constructed during the course of the study. High spectral resolution is important when producing color composite images. The rule of color composites is to set the most informative band for a particular purpose in the red, the next in green and the least informative band in blue filters (Drury 1993). The different RGB combinations discriminate the rock types which is useful in geological application. Any three bands of the six OLI bands can produce color composite image.

A false color composite of bands 7, 5, 3 in RGB, respectively, was assembled in this work as shown in Fig. 4.

On this image, the sheared acid meta-volcanic appears in dark brown color and has linear shapes with the general trend of northeast-southwest (NE-SW), while the basic meta-volcanic appears in light brown color. The silica barite
Fig. 3 The flowchart of the adopted methodology

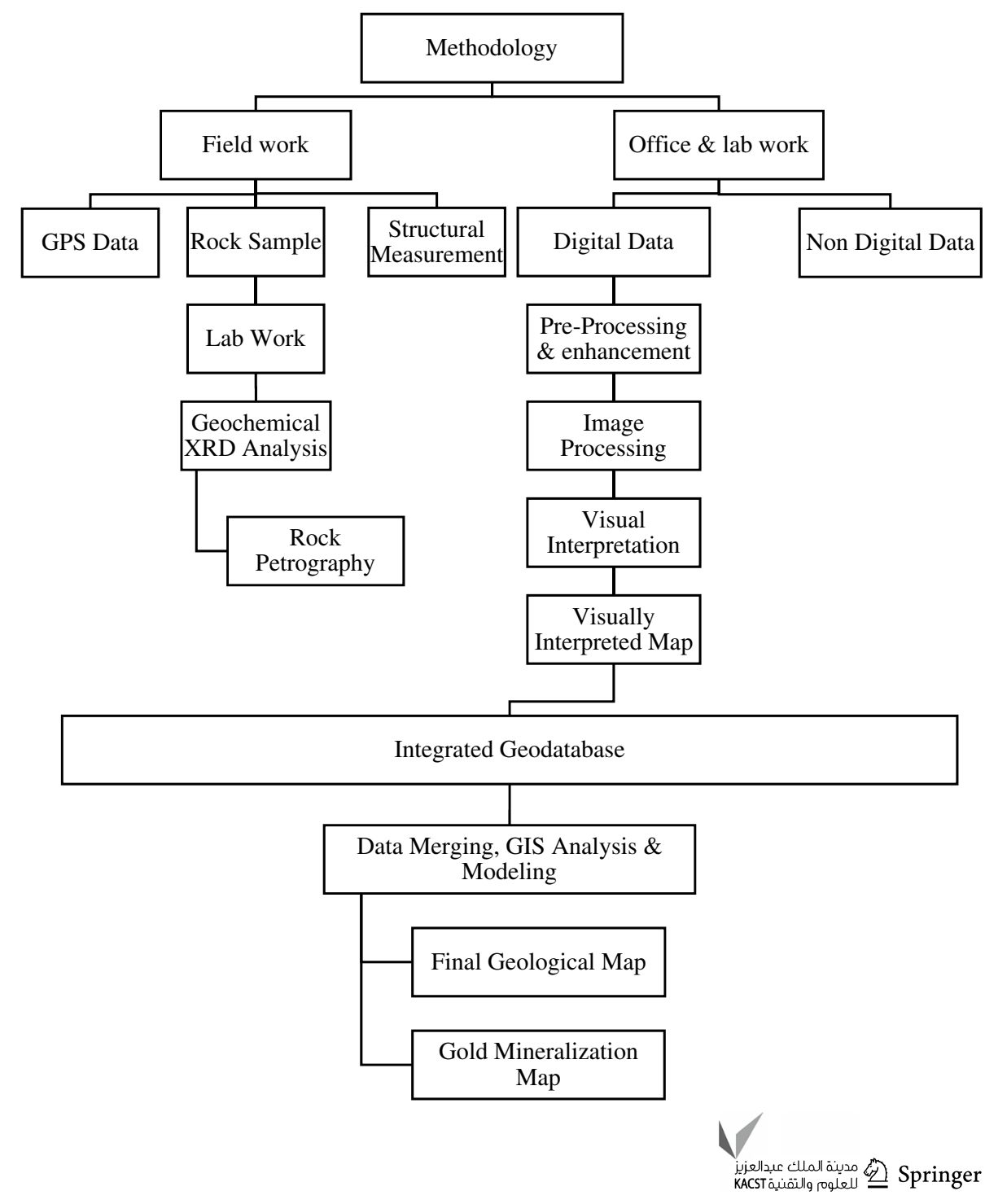


Fig. 4 Landsat OLI color composite obtained using bands 7 , 4, 3 in RGB, respectively

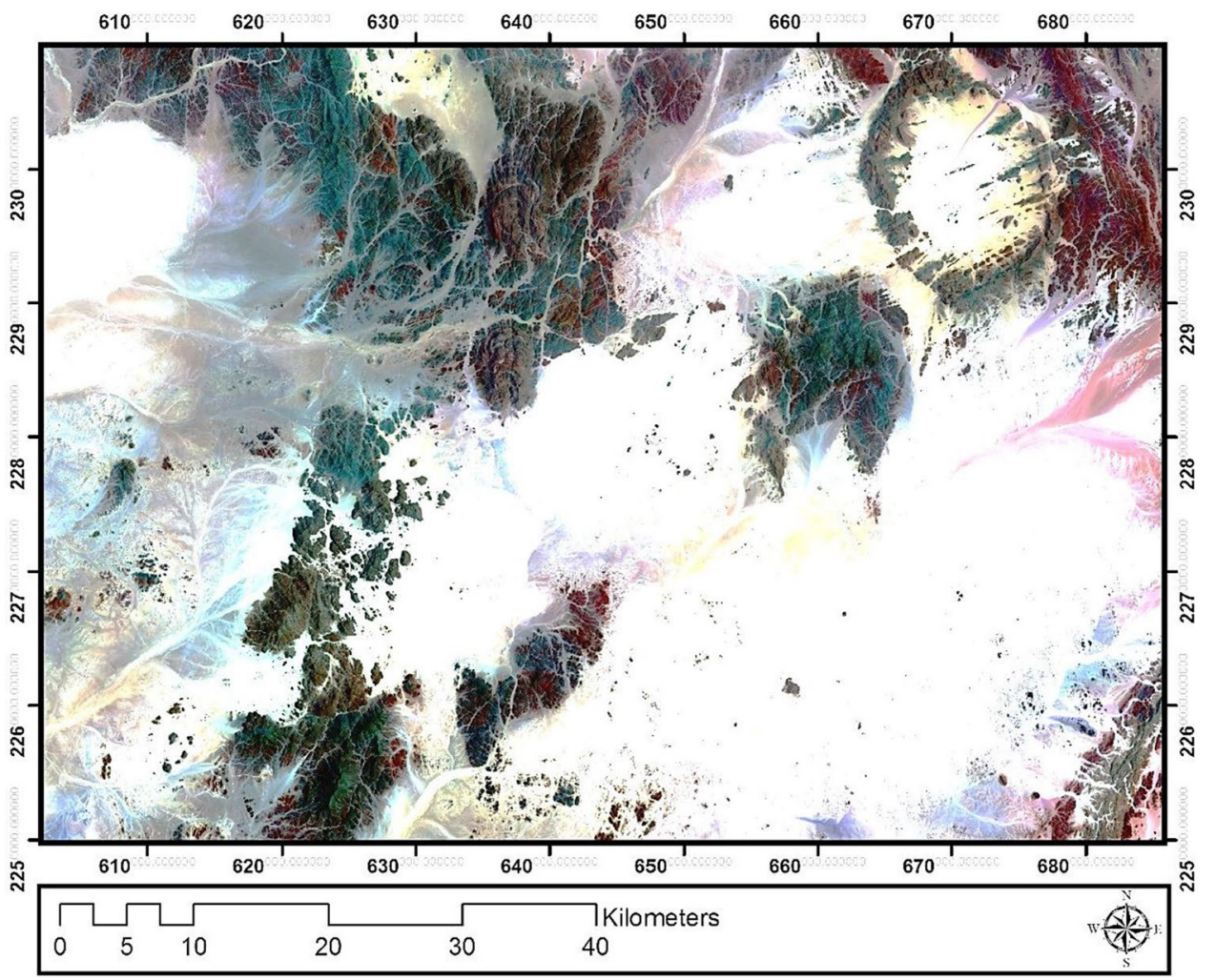

Fig. 5 Landsat OLI color composite obtained using bands 7 , 6,5 in RGB, respectively

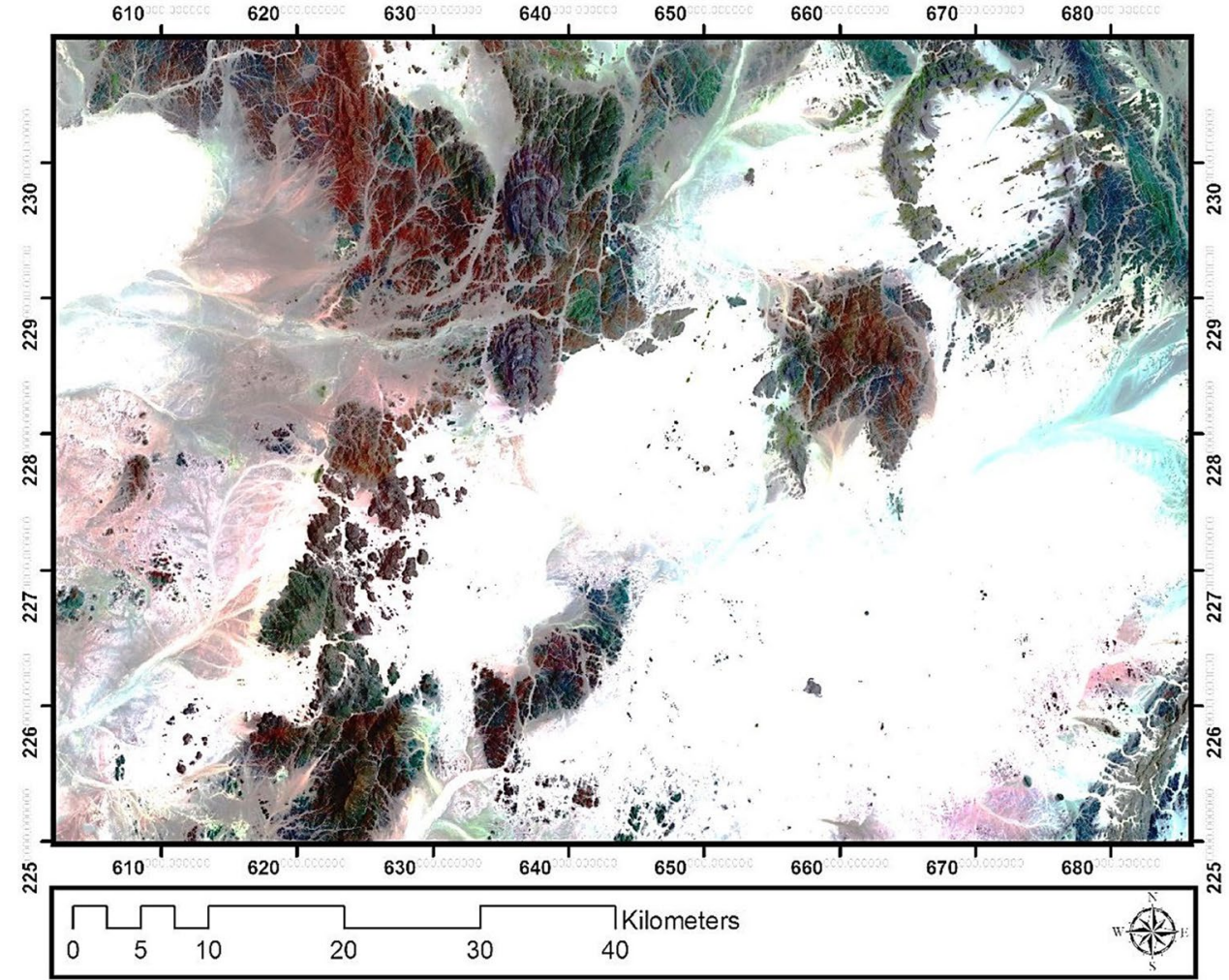

is light green in color and the intrusive granite appears brighter and has spot shape which makes it easily discernible from other rock units and has sharp contact with the adjacent rock units. 


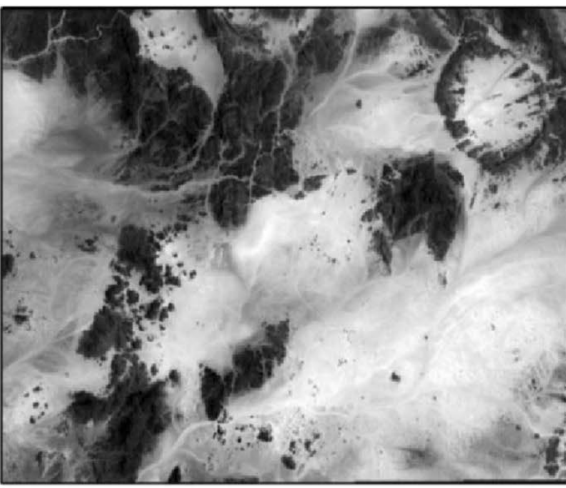

PC 1

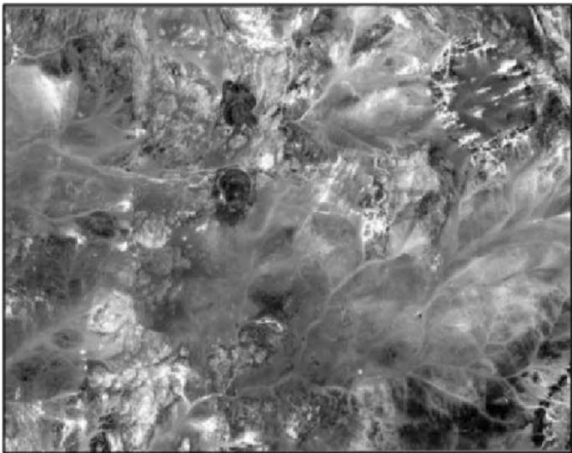

PC 4

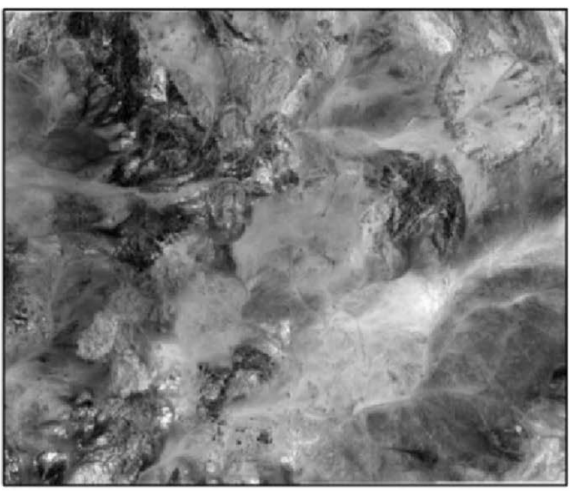

PC 2

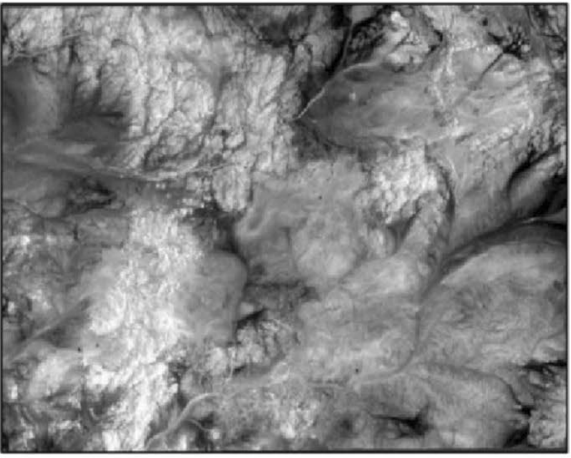

PC 5

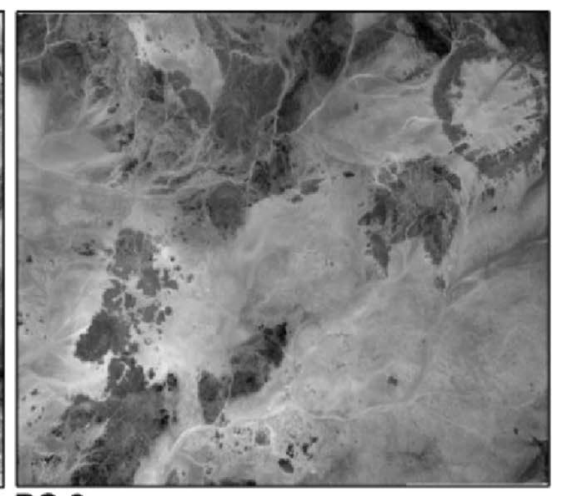

PC 3

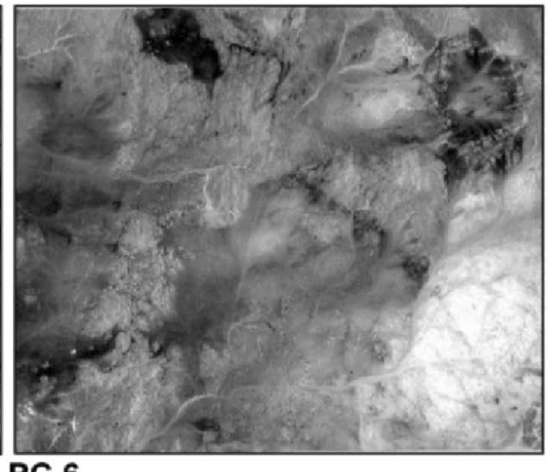

Fig. 6 Six principal component images obtained transforming the six reflective OLI bands

Another color composite was prepared using the infrared bands of the image set. It was composed by employing bands 7, 6, 5 in RGB, respectively, as shown in Fig. 5. This band combination is termed the infrared image.

Using the six reflective OLI multispectral bands, principal component analysis (PCA) was performed over the study area.

New axes of principal component analysis were computed statistical analyses. This procedure resulted in the production of six principal component images illustrated in Fig. 6

The first PC image contains the largest percentage of data variance, and by comparison, the variance in last PCs image is seen to be negligible due to the fact that the image appears totally noisy and contains no information.

Principal components produced more colorful color composite images than spectral color composite images because of the uncorrelated nature of the obtained PC images.

PC1 and PC2 display more lithological contrast, the topographic expression is better, and it is known that they discriminate well between the visible and near-infrared (VNIR) and shortwave infrared (SWIR) bands. Although PC3 and PC4 have low variance values, they still display fair lithological contrast, whereas PC5 and PC6, with very low variance values, are less informative and show more noise.
The principal component color composite (Fig. 7) was created by assaying the PC1, PC2 and PC 3 to the RGB filters, respectively. Composite images of PC1, PC2 and PC3 in RGB and PC2, PC 3 and PC4 in RGB have provided much lithological information and discrimination between rock units.

\section{Rationing technique}

Image ratioing is one of the change detection techniques used in remote sensing. Change detection is the process of identifying differences in the state of an object or phenomenon by observing it at different times (Singh 1989).

Spectral band rationing is a proven technique which allows identification of geological materials based on the reorganization of diagnostic absorption bands. It minimizes the effect of topographic slope, aspect, and Albedo differences between rocks and enhances the subtle differences in reflectivity between bands which are diagnostic of various surface materials (Estes 1983). Ratio images are prepared by dividing the DN (digital number) value in one spectral band by the corresponding DN value in another band for each pixel (Sabins 2000; Afify 2011). Band rationing has been used successfully with Landsat data for identifying the hydrothermally altered rocks, particularly volcanic rocks,

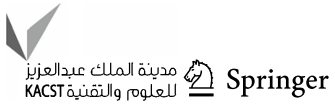


Fig. 7 Principal component analysis color composite obtained by assaying PC1, PC2, PC3 to RGB, respectively

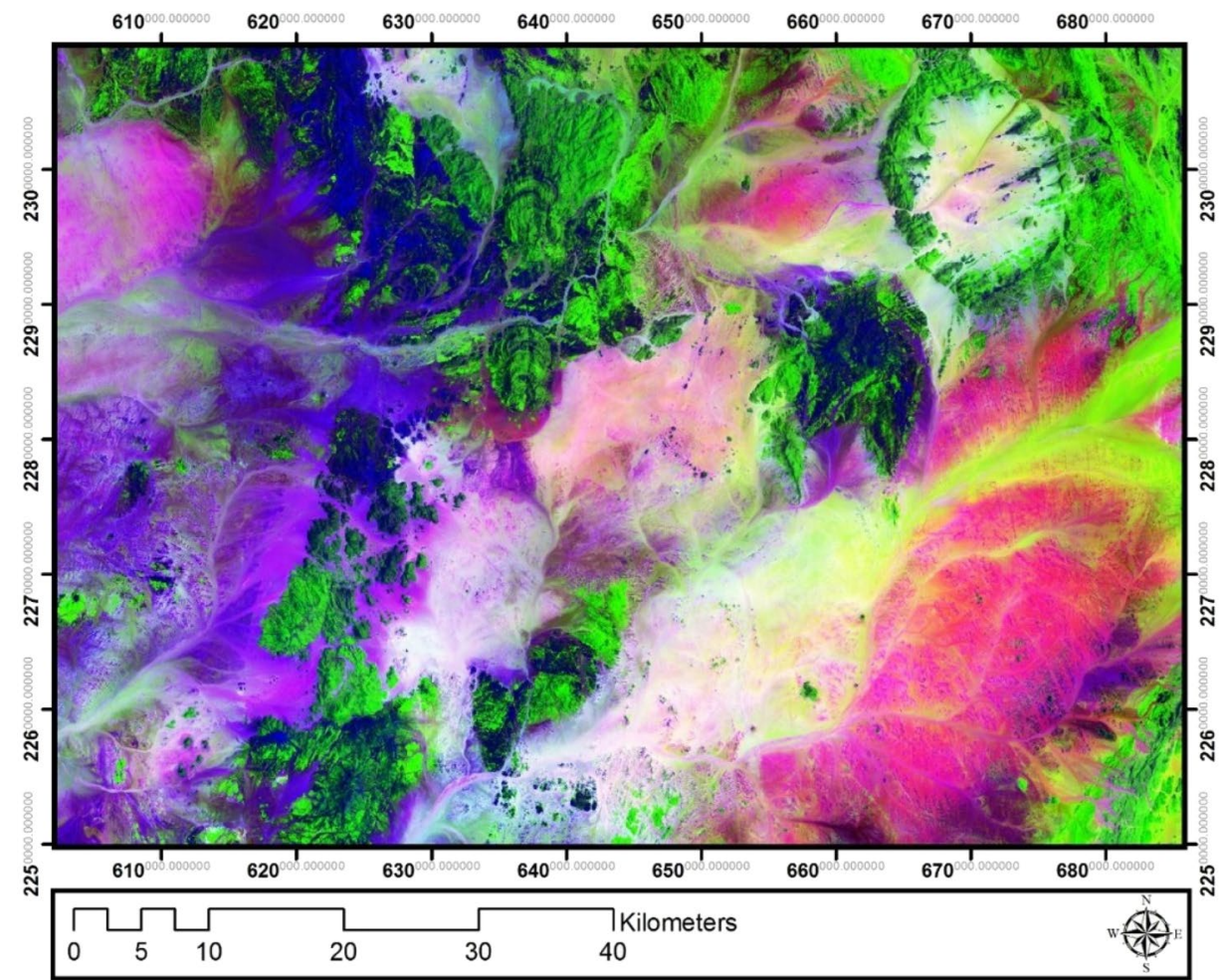

Table 1 The different combinations of ratio images

\begin{tabular}{lll}
\hline Author & Landsat 7 ETM+ & Landsat 8 OLI \\
\hline Sultan et al. (1987) & $5 / 7,5 / 1,(3 / 4) *(5 / 4)$ & $6 / 7,6 / 2,(4 / 5) *(6 / 5)$ \\
Mineral composite & $6 / 7,7 / 4,3 / 1$ & $6 / 7,7 / 5,4 / 2$ \\
Hydrothermal com- & $5 / 7,3 / 1,4 / 3$ & $6 / 7,4 / 2,5 / 4$ \\
posite & & \\
\hline
\end{tabular}

which are characterized by minerals such as sericite, jarocite, alunite and clay minerals that have relatively narrow absorption bands in the $2.2 \mu \mathrm{m}$ region (Hunt 1979).

Ratio images are known for enhancement of spectral contrasts among the bands considered in the rationing and have successfully been used in mapping alteration zones (Segal 1983; Kenea 1997). During this study, several ratio images were prepared for the purpose of geological mapping and alteration zones delineation. Generally, the OLI 4/2 image ratio shows high values for iron stained hydrothermally altered rock and ferric oxides because iron minerals have low reflectance in band 2 and high reflectance in band 4, while the OLI6/7 ratio is used to enhance the hydroxyl-bearing minerals and distinguishes altered rocks containing clays and alunite from unaltered rocks. Several OLI bands ratio have been computed: $6 / 7,6 / 5,6 / 2,4 / 2,5 / 4$ and $4 / 5$.

Based on the spectral features of ferric and hydroxylbearing minerals, two ratio false color composite images were produced by combining three ratio images at a time in
RGB. The different combinations of ratio images are shown in Table 1, and this provides the computation suitable for use with Landsat 7 ETM+images and Landsat 8 OLI images.

Sultan et al. (1987) used Thematic Mapper (TM) 5/1 ratio (equivalent to OLI 6/2 ratio images) because opaque minerals have reflectance features in band 5 and absorption features in band 1. Sultan's color composite ratio image was obtained by using OLI image ratios which corresponds to TM image ratios as $6 / 7,6 / 2$ and $4 / 5 * 6 / 5$ in $\mathrm{R}, \mathrm{G}$ and B, respectively. The resultant image (Fig. 8) shows that the acid meta-volcanic rocks appear bluish in color, the metasediment reddish in color, the sheared granite in deep blue color, the post-tectonic granite appears brighter, and the clay minerals appear in pink.

Mineral's composite ratio image was obtained using OLI band ratios $6 / 7,7 / 5$ and $4 / 2$ in RGB, respectively. The obtained image (Fig. 9) shows meta-volcanic in reddish, while the meta-sediment is in light green color and easily discernible from other rock units. The alteration zone is mapped in reddish yellow.

\section{Geology}

The study area is covered by different lithological units with predominant acid meta-volcanic rocks and syn-tectonic granite in addition to various post tectonic rocks. There is also the presence of few scattered low laying outcrops of 
Fig. 8 Sultan's Color composite of band ratios $(5 / 7),(5 / 1)$, and $(3 / 4 * 5 / 4)$ in RGB, respectively
Fig. 9 Mineral composite image obtained using the combination $(5 / 7),(5 / 4),(3 / 1)$ in RGB, respectively
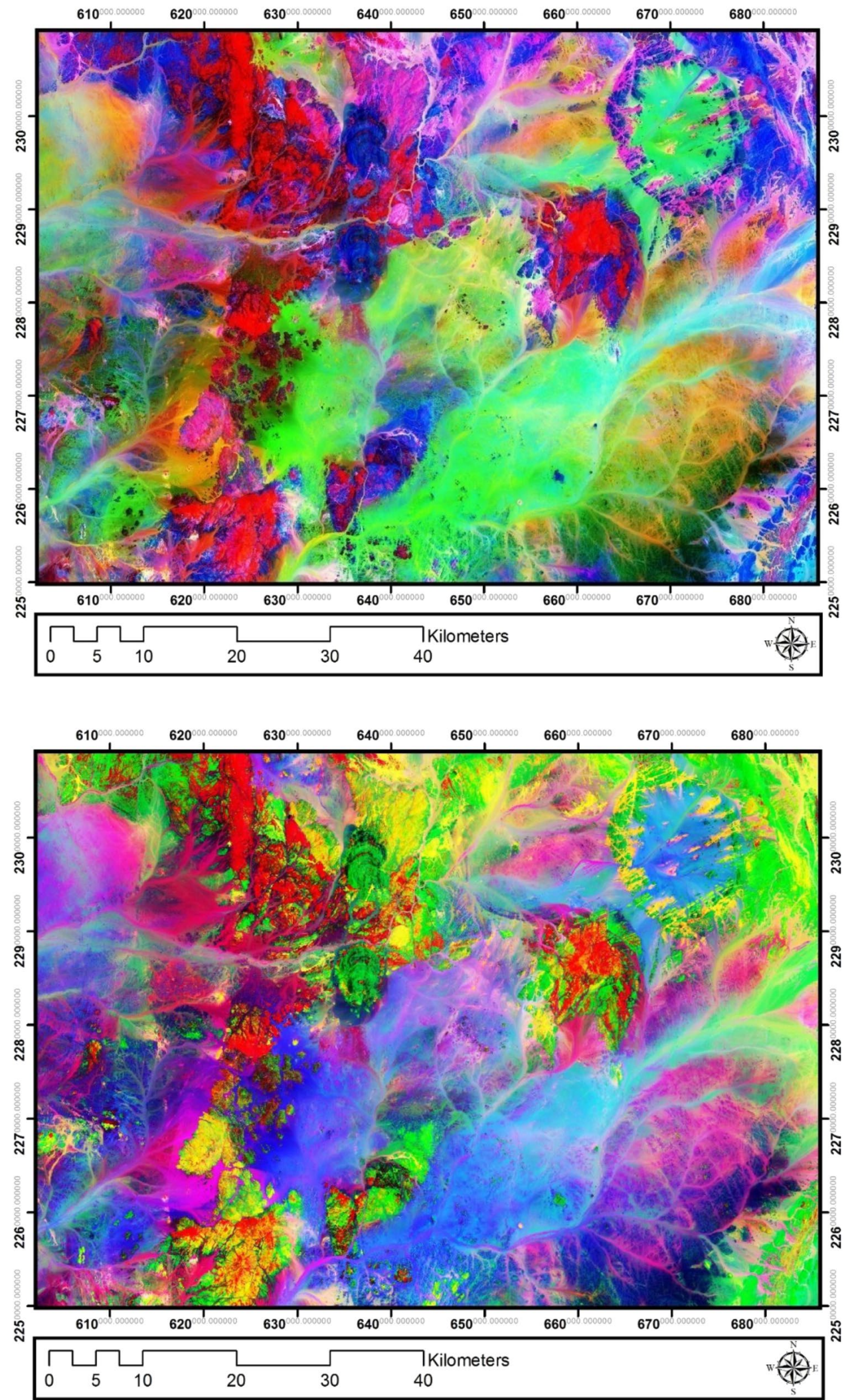

sedimentary rocks and superficial deposits. Figure 10 is a map showing the regional geology of the study area.
From the field description and geochronological result, the study area is commonly characterized by Mylonites rocks that are called generally meta-volcano sedimentary/ 


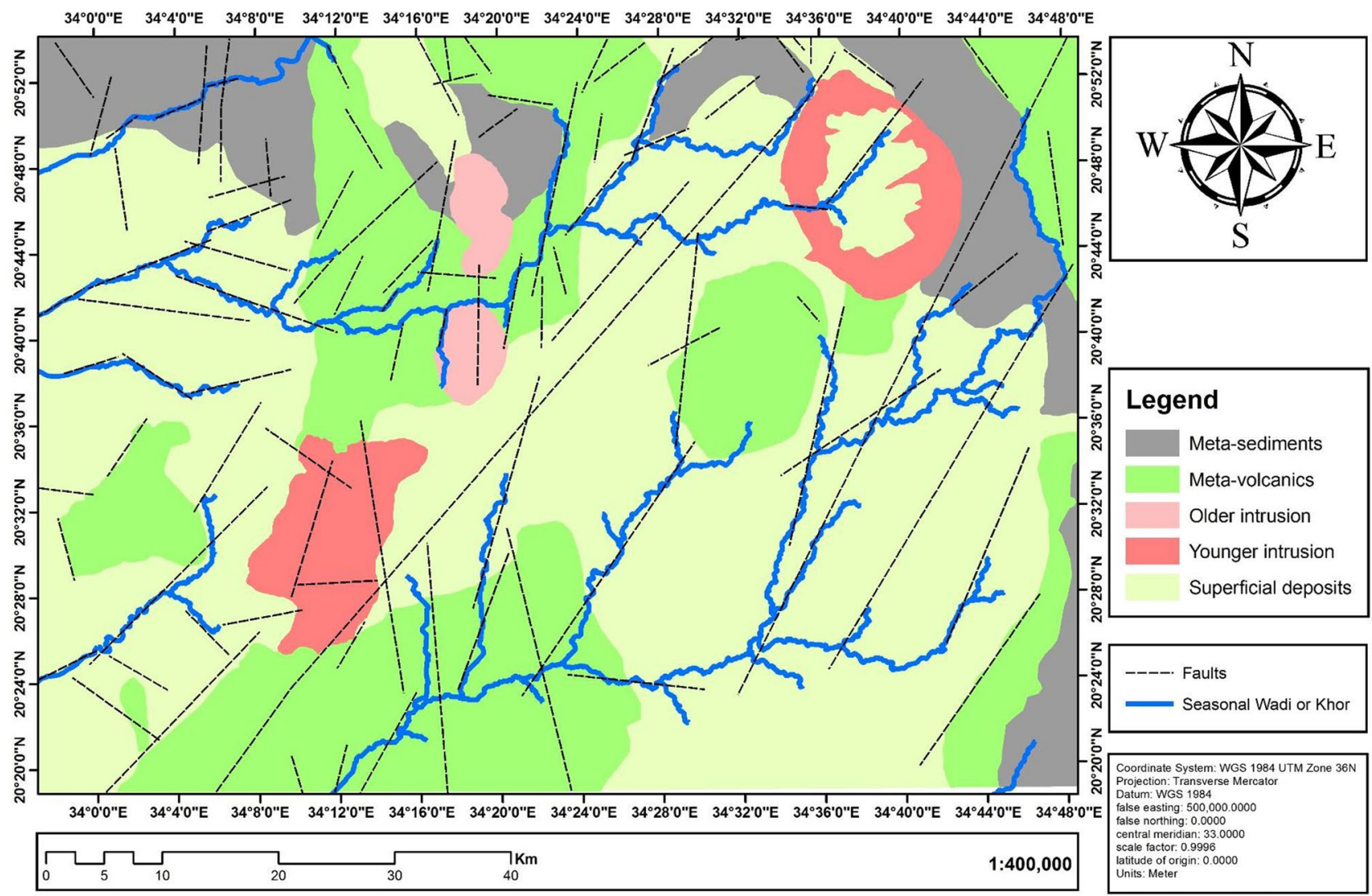

Fig. 10 Regional geological map of the study area

Table 2 Rocks in the study area and their characteristics

\begin{tabular}{|c|c|c|c|}
\hline Class of deposits & Class representatives & Remarks & Texture/Mineralogy \\
\hline Meta-sediments & $\begin{array}{l}\text { Quartzite } \\
\text { marble }\end{array}$ & $\begin{array}{l}\text { Oldest rock unit in the area } \\
\text { They occur in linear form generally trending } \\
\text { in E-W direction }\end{array}$ & $\begin{array}{l}\text { Quartzite is pinkish in color, coarse grained } \\
\text { and contains quartz and malachite } \\
\text { Marble is gray, coarse grained and highly } \\
\text { sheared. It is filled with calcite and inter- } \\
\text { granular quartz }\end{array}$ \\
\hline Meta-volcanics & $\begin{array}{l}\text { Metatrachyte } \\
\text { Meta-acid volcanic }\end{array}$ & $\begin{array}{l}\text { They occur in form of surface outcrops and } \\
\text { also in form of mountain outcrops }\end{array}$ & $\begin{array}{l}\text { Metatrychyte is dark, highly weathered and } \\
\text { of medium texture. It contains calcite } \\
\text { Meta-acid volcanic is gray, fine grained with } \\
\text { malachite as the secondary mineral }\end{array}$ \\
\hline Syn-orogenic granitoids & $\begin{array}{l}\text { Granite } \\
\text { granodiorite }\end{array}$ & $\begin{array}{l}\text { These are the older, fine-coarse grained, } \\
\text { intrusive granitoids }\end{array}$ & $\begin{array}{l}\text { Granodiorite is highly weathered and coarse } \\
\text { to medium grained. It is composed of } \\
\text { quartz k-feldspar and biotite }\end{array}$ \\
\hline Post-orogenic & $\begin{array}{l}\text { Porphyritic microganite } \\
\text { granodiorite } \\
\text { Quartz feldspar porphyry }\end{array}$ & They occur as non-foliated intrusions & $\begin{array}{l}\text { Porphyritic microgranite is light gray, coarse } \\
\text { grained and highly weathered. It contains } \\
\text { quartz, alkali feldspar and plagioclase } \\
\text { Granodiorite is highly sheared and dark- } \\
\text { colored. It is coarse to medium grained, } \\
\text { and composed of quartz, hornblende and } \\
\text { subordinate orthoclase } \\
\text { Quartz feldspar porphyry is brecciated and } \\
\text { composed of angular fragments of quartz }\end{array}$ \\
\hline
\end{tabular}

Superficial deposits

Active and recently active sand sheets

Amalgamated dunes
They are the latest rock units in the study area 

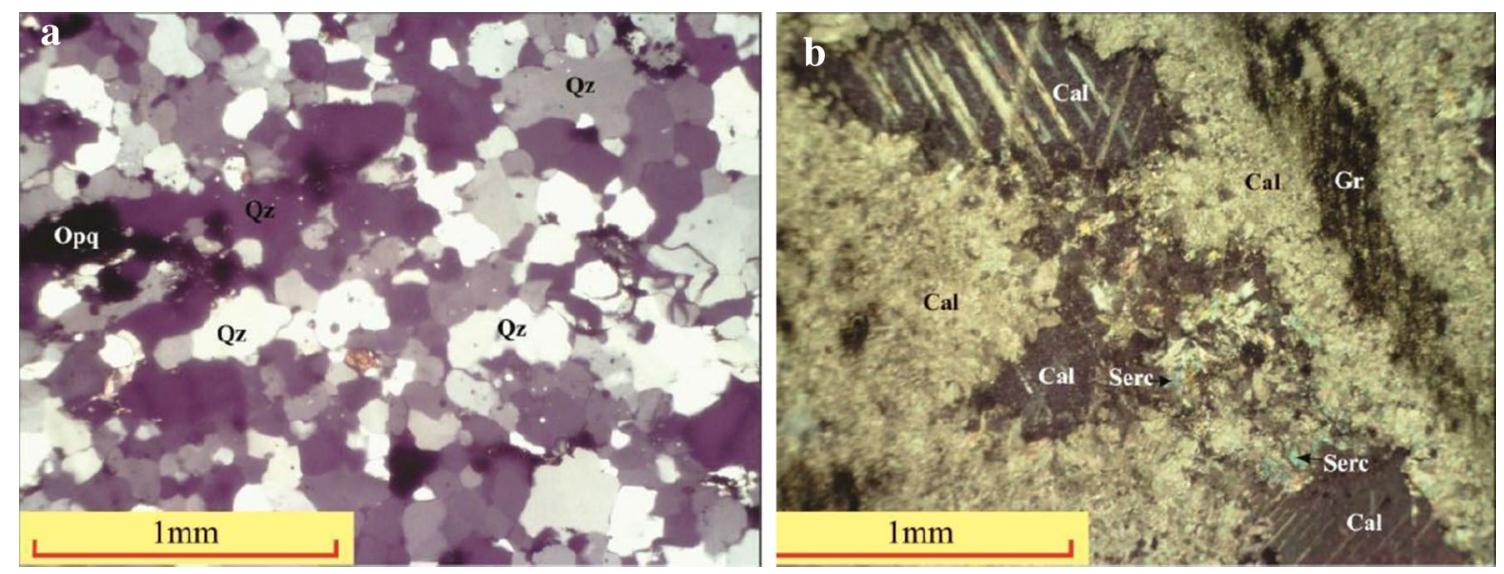

Fig. 11 a Photomicrograph of quartzite (RO-24, 1) b Photomicrograph of marble (SA-37, 1)
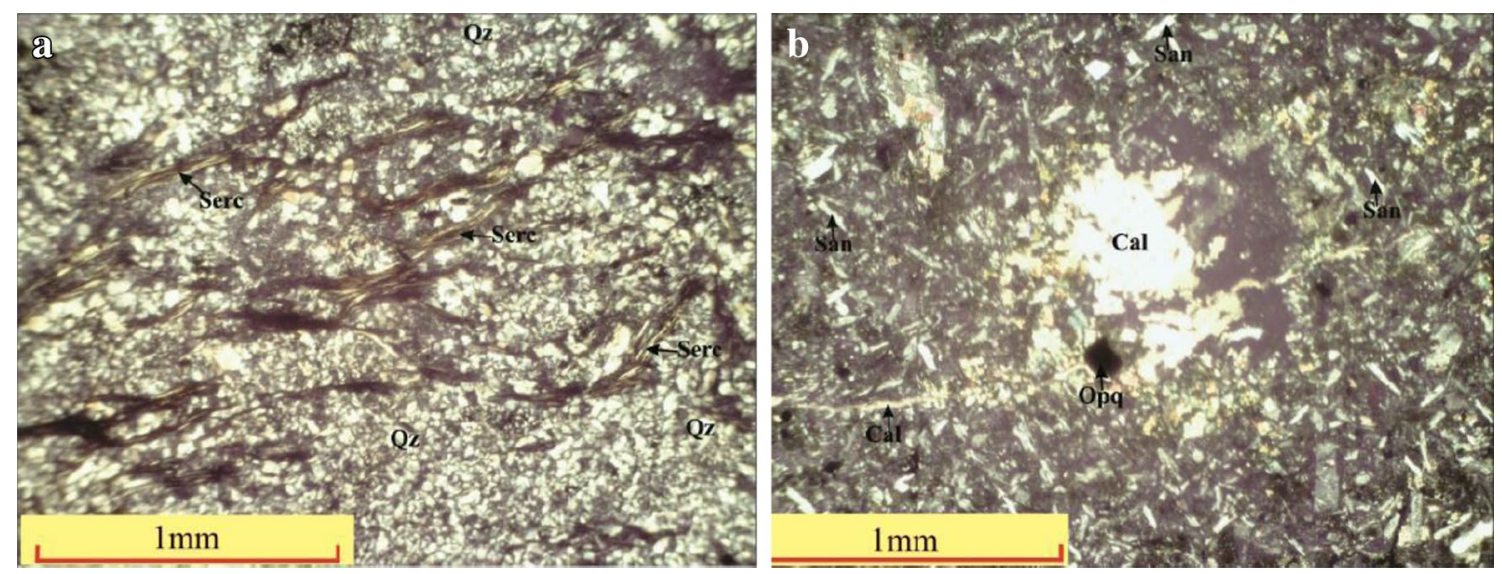

Fig. 12 a Phtotomicrograph of meta-rhyolite $(\mathrm{RO} 1-1,1)$ b Photomicrograph of meta-trachyte $(\mathrm{RO} 15,1)$
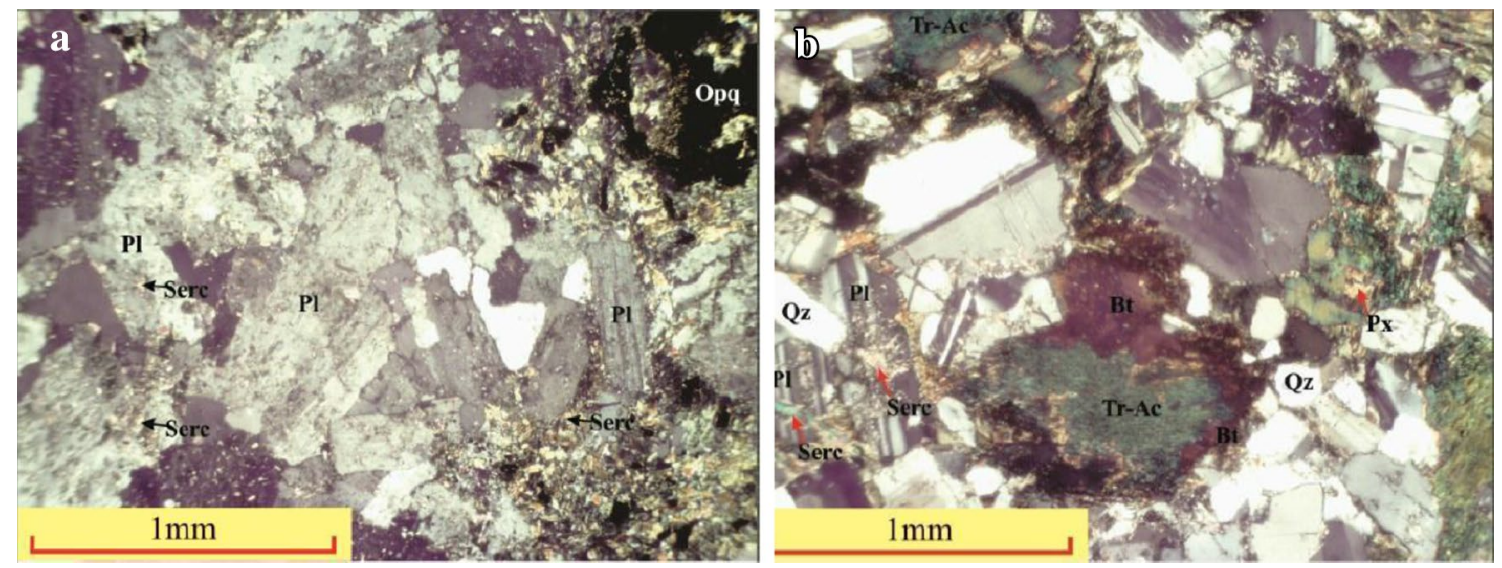

Fig. 13 a Photomicrograph of granodiorite (RO-08, 2) b Photomicrograph of meta-gabbro (RO-43, 1)

plutonic sequences. The table below highlights the occurrence and properties of these rocks (Table 2).
Figure 11 shows photomicrographs of quartzite and marble, representing the meta-sediments. In the same vein,

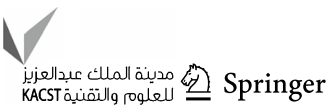



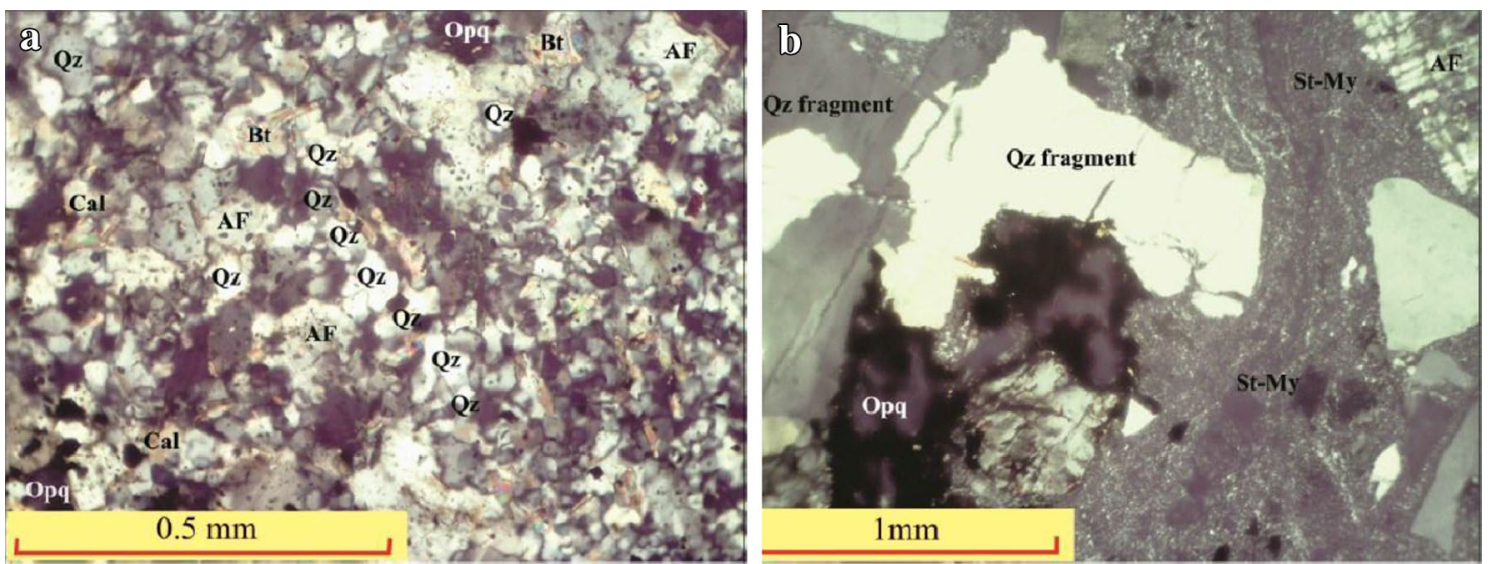

Fig. 14 a Photomicrograph of porphyritic microgranite (RO-05) b Photomicrograph of quartz-feldspar porphyry (RO-25-2,2)

Fig. 15 Lineament map of the study area

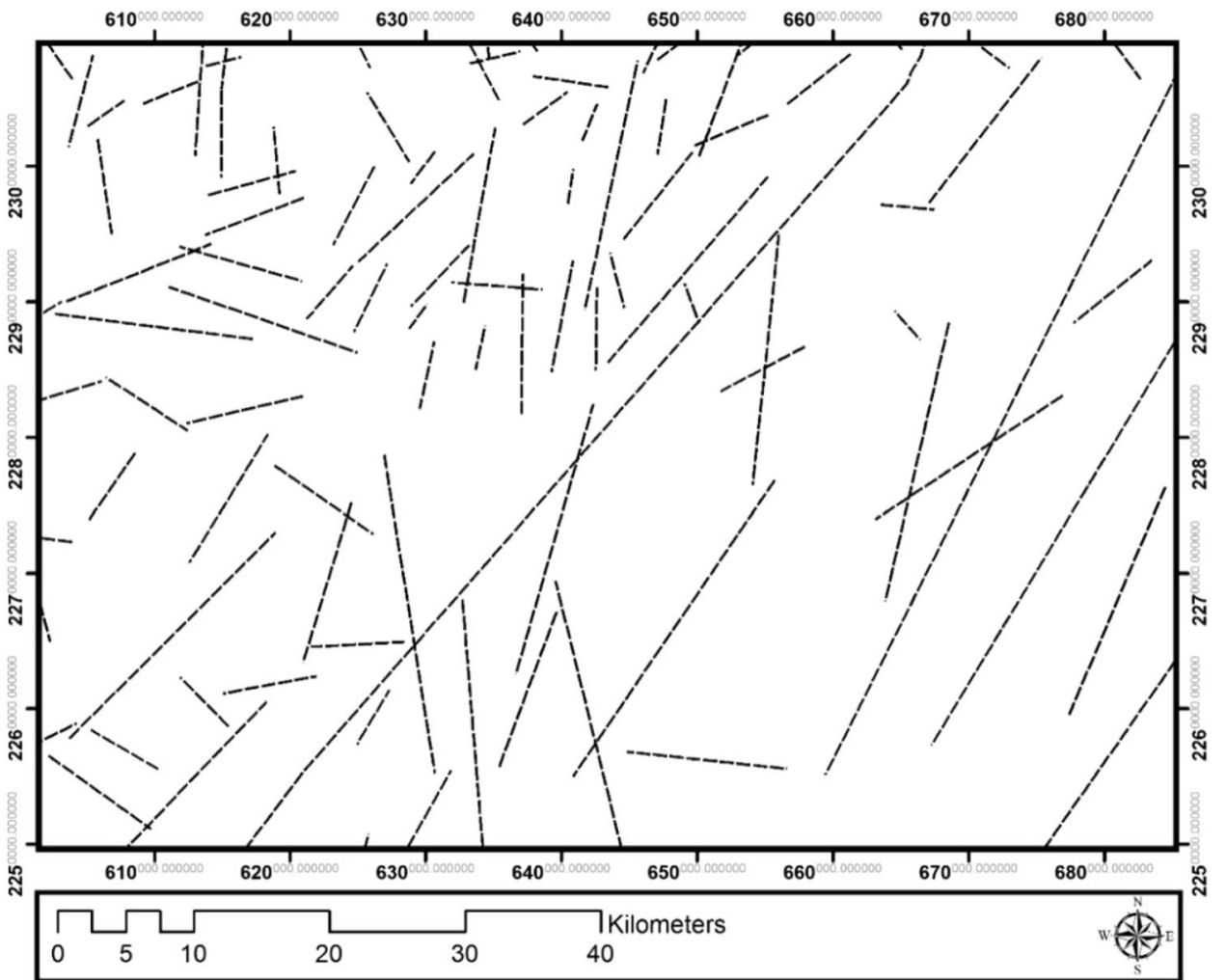

the photomicrographs of the meta-volcanics, syn-orogenic granitoids and post-orogenic rocks are given in Figs. 12, 13, 14 , respectively.

\section{Structure}

The most pronounced structural features in the study area are the presence of faults. They have the general trends of northeast-southwest (NE-SW), northwest-southeast (NW-SE) and east-west (E-W) (Fig. 15). Most of these faults are strike-slip where the dominant displacement is horizontal and parallel to the strike of the fault. The evidences of these faults are the rocks brecciation, shearing, ferruginization and slickensides.

\section{Prospecting for minerals}

\section{Alteration zones}

The breakdown of feldspars and ferromagnesian minerals to a variety of clays and other hydroxyl bearing minerals is the commonest type of alteration. Such minerals can be detected 
by remote sensing techniques since the shortwave infrared (SWIR) range of their spectra exhibit absorption (Drury 1993). It has been well established that ferric iron exhibits pronounced absorption features at around $0.82 \mu \mathrm{m}$ and $1.3 \mu \mathrm{m}$ (infrared region), whereas ferrous iron has absorption at $1.0 \mu \mathrm{m}, 4.8-2.0 \mu \mathrm{m}$ and $0.55-0.45 \mu \mathrm{m}$ (Ultra-violet and violet range). Hydroxyl-bearing minerals such as clays have a major absorption feature around $1.9 \mu \mathrm{m}, 2.35 \mu \mathrm{m}$ and $2.5 \mu \mathrm{m}$ (band 7) (Gupta 2003). Detection of the above mentioned minerals has been used as prospecting guide for ore deposits.

To fulfil the objectives of the present study, alteration zone mapping was conducted using Landsat OLI image applying different digital image procedures, such as rationing technique and feature oriented principal component analysis. The results of the different techniques utilized to this end are presented in this section.

\section{Mapping alteration zones using rationing techniques}

Extensive hydrothermal alteration zones and weathering of the sulphide mineralization within the acid volcanic represent a significant mineral province in the Red Sea Hills of Sudan (Robertson Research International, RRI 1985). False color composite image called the hydrothermal composite because of its ability to enhance hydrothermal wall rock alteration was produced using combination of bands $5 / 7$, 3/1, 4/3 in R, G, B, respectively (Fig. 16).
On this image, the altered rocks appear in reddish-pink colors. These alteration zones are observed along linear structures trending NE-SW in the acid meta-volcanic rocks.

\section{Mapping alteration zones using feature oriented principal component analysis}

This method was created by Crosta and McMoore (1989) with the purpose of using remote sensing satellite images for geological exploration in an environment lacking bedrock exposure and whereby selected bands believed to contain

Table 3 Band statistics and eigenvector loadings (A) for iron-oxide mapping using TM bands 2, 4, 5, and 7, and (B) for hydroxyl mapping using bands $2,5,6$, and 7

\begin{tabular}{lllll}
\hline & B.02 & B.04 & B.05 & B.07 \\
\hline$A$ & & & & \\
PC 1 & 0.28 & -0.72 & 0.63 & -0.06 \\
PC 2 & 0.50 & -0.22 & -0.41 & 0.72 \\
PC 3 & 0.58 & -0.10 & -0.44 & -0.68 \\
PC 4 & 0.58 & 0.65 & 0.49 & 0.08 \\
$B$ & & & & \\
PC 1 & 0.26 & 0.84 & -0.47 & 0.01 \\
PC 2 & 0.53 & 0.28 & 0.79 & 0.08 \\
PC 3 & 0.60 & -0.30 & -0.22 & -0.71 \\
PC 4 & 0.54 & -0.35 & -0.31 & 0.70 \\
\hline
\end{tabular}

Fig. 16 Ratio image color composite produced using the following ratios $6 / 7,4 / 2,5 / 4$ in $\mathrm{R}, \mathrm{G}, \mathrm{B}$, respectively. Red circles are samples collected for geochemical analysis

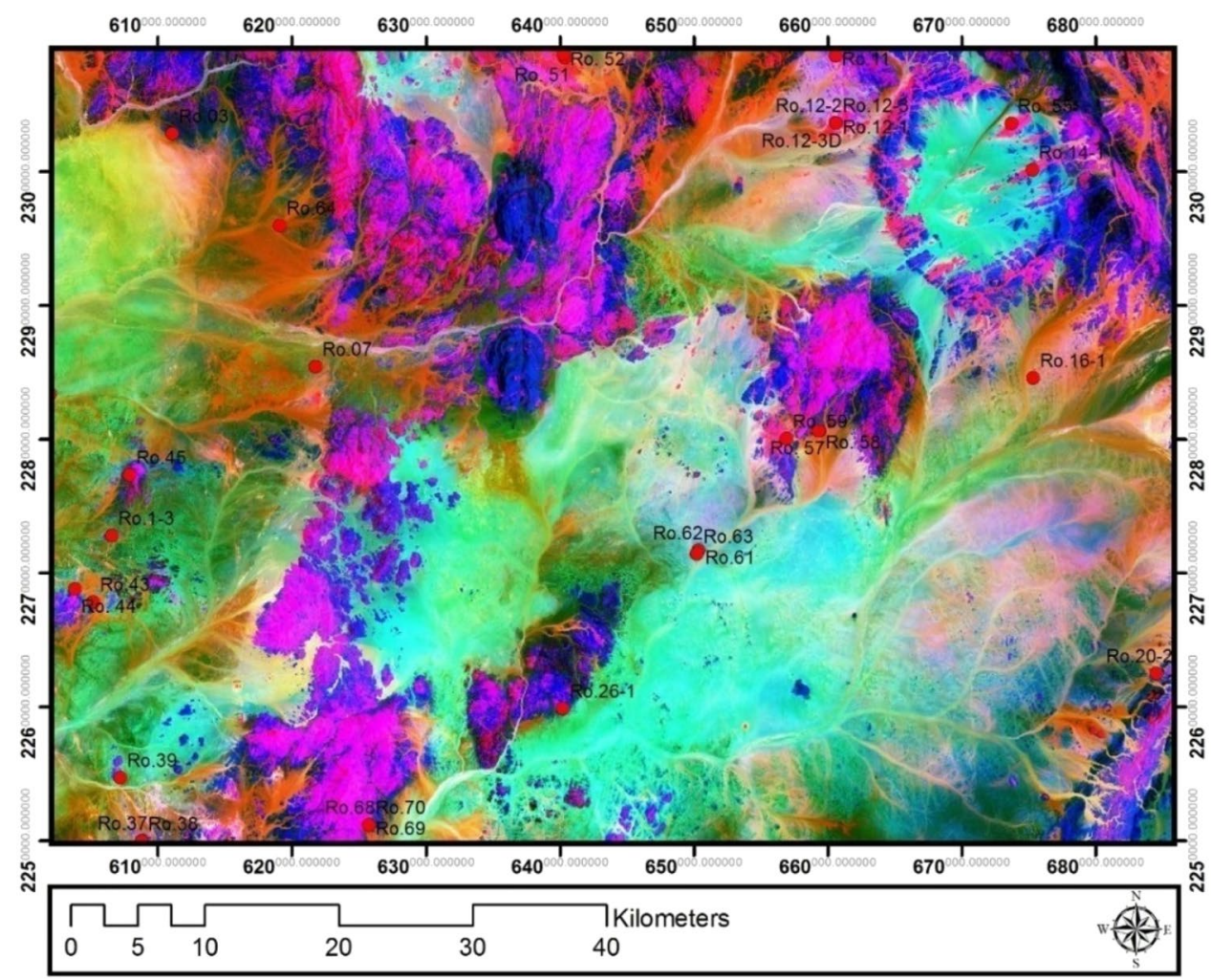


spectral information over an intended target are used in PC transformation.

For enhancement of both iron-oxides and hydroxyl-bearing zones, two sets of four TM bands were selected: bands $1,3,4$ and 7, and 1, 4, 5 and 7. This selection is based on the fact that the former have contrasting signatures in TM bands 1 and 3, and the latter in TM bands 5 and 7 (Loughlin 1991). The above described two PC transformations were conducted for the study area.

Table 3 summarizes the basic statistics of the bands involved in the transformation and gives the eigenvector loadings of both band sets. As it is clear from Table 3, PC4 has mapped iron-oxides as negative loading $(-0.77)$ in TM-3 and as (0.13) in TM-1. For hydroxylated minerals (Table 3 ), PC4 has relatively more contrasting signature loading (-0.69) in TM-5 and (0.70) in TM-7.

PC3 was selected from the first transformation to map the iron oxide. PC4 was selected from the second transformation to map the hydroxyl-bearing minerals. A linear combination of the two PCs was produced to map the hydroxyl-bearing minerals and iron oxides. A composite image was prepared by combining the "hydroxyl," hydroxyl+iron-oxide and iron oxide images in RGB, respectively. A low pass spatial filtering of $3 \times 3$ kernel was run in order to remove the incorporated significant noise and improving the hue by removing isolated pixels smaller than the applied window size. The obtained image is displayed in Fig. 17. On this image, all alterations have been mapped in brownish golden color.

\section{X-ray fluorescence (XRF) analysis}

Groundtruthing and field check-up were made to authenticate the results obtained by the alteration zone mapping through satellite image interpretation. Geochemical samples (Table 4) were collected from quartz vein and alteration host rocks.

The geochemical analysis results show that the highest anomaly value for gold is $43.913 \mathrm{ppm}$ and the lowest is 0.009 ppm. Results from the work of Elsayed (2010) from five outcrop surfaces around the Red Sea Hills showed gold content ranging from $1.1 \mathrm{ppm}$ to $12.2 \mathrm{ppm}$ in sample AZ2. It is clear from the results of the geochemical analysis as well as geological mapping and alteration zone mapping that the area is highly prospective for gold. Therefore, this area is extremely encouraging for further ground survey and exploration work.

\section{Conclusion}

Remote sensing technique has proved a powerful method for large scale geological mapping in relatively short time and with a reasonable degree of exactness. This mapping is of great importance since the exploration of any given area must start with geological mapping. However, care must be taken in the usage of satellite images as base maps
Fig. 17 Principal component analysis color composite obtained by assigning hydroxyl," hydroxyl+ironoxide and iron-oxide images in $\mathrm{R}, \mathrm{G}$, and B, respectively (Red circles are samples collected for geochemical analysis)

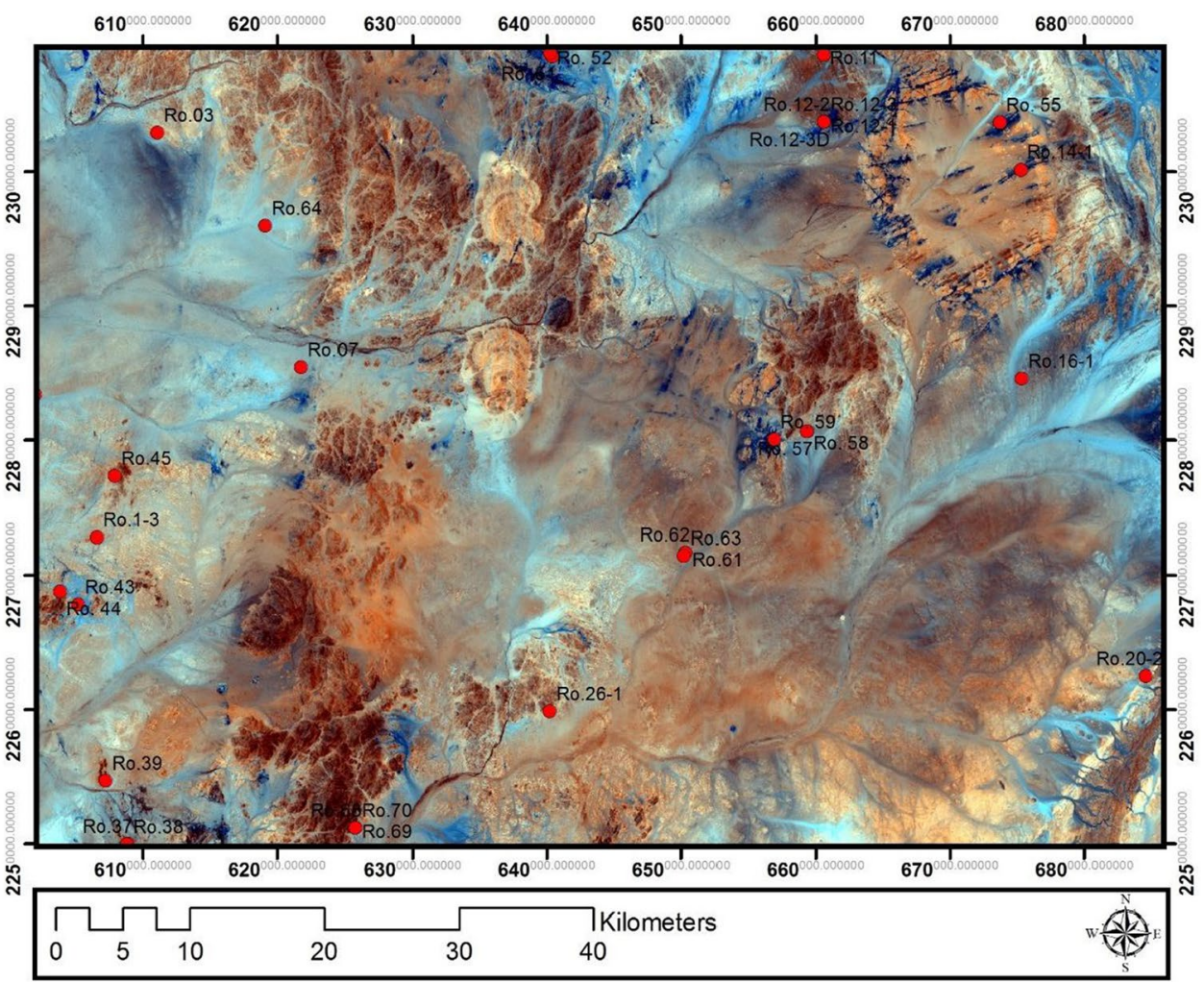


Table 4 The geochemical samples and their analysis

\begin{tabular}{|c|c|c|c|c|c|c|c|c|c|}
\hline Long & Lat & Sample & Au ppm (1) & Au ppm (2) & Long & Lat & Sample & Au ppm (1) & $\mathrm{Au} \mathrm{ppm} \mathrm{(2)}$ \\
\hline 603,776 & $2,268,801$ & Ro. 44 & 0.123 & & 660,637 & $2,303,631$ & Ro.12-3B & 0.073 & \\
\hline 640,424 & $2,308,513$ & Ro. 51 & 0.07 & & 660,638 & $2,303,632$ & Ro.12-3C & 43.913 & 6.014 \\
\hline 640,288 & $2,308,780$ & Ro. 52 & 0.069 & & 660,637 & $2,303,632$ & Ro.12-3D & 0.009 & 0.559 \\
\hline 673,745 & $2,303,587$ & Ro. 55 & 0.074 & & 675,312 & $2,300,115$ & Ro.14-1 & 0.065 & \\
\hline 659,399 & $2,280,639$ & Ro. 57 & 0.087 & & 675,384 & $2,284,593$ & Ro.16-1 & 0.045 & \\
\hline 659,363 & $2,280,621$ & Ro. 58 & 0.086 & & 684,572 & $2,262,506$ & Ro.20-2 & 0.082 & \\
\hline 611,056 & $2,302,855$ & Ro.03 & 0.086 & & 640,237 & $2,259,887$ & Ro.26-1 & 0.043 & \\
\hline 619,107 & $2,295,975$ & Ro.64 & 0.122 & & 608,840 & $2,250,005$ & Ro. 37 & & 0.288 \\
\hline 605,156 & $2,267,817$ & Ro.43 & 0.108 & & 608,750 & $2,249,933$ & Ro. 38 & 0.029 & \\
\hline 607,843 & $2,277,344$ & Ro. 45 & 0.187 & & 607,169 & $2,254,718$ & Ro.39 & 0.029 & 0.299 \\
\hline 625,731 & $2,251,192$ & Ro.69 & 0.11 & & 601,937 & $2,283,391$ & Ro.46 & 0.047 & \\
\hline 621,766 & $2,285,435$ & Ro.07 & 0.422 & & 650,358 & $2,271,682$ & Ro.61 & 0.646 & 2.476 \\
\hline 660,636 & $2,308,649$ & Ro. 11 & 0.172 & 1.014 & 650,358 & $2,271,681$ & Ro.62 & 1.46 & \\
\hline 660,637 & $2,303,632$ & Ro.12-1 & 0.24 & & 650,245 & $2,271,428$ & Ro.63 & 1.968 & 3.22 \\
\hline 660,637 & $2,303,633$ & Ro.12-2 & 0.029 & & 625,731 & $2,251,191$ & Ro.68 & 0.039 & \\
\hline 660,638 & $2,303,632$ & Ro.12-3 & 0.107 & & 625,731 & $2,251,193$ & Ro. 70 & 0.072 & \\
\hline 660,638 & $2,303,632$ & Ro.12-3A & 0.088 & & 606,541 & $2,272,811$ & Ro.1-3 & 2.048 & 2.02 \\
\hline
\end{tabular}

for geological mapping as different rock types have similar reflectance properties.

The use of remote sensing in such areas as the Red Sea Hills must be considered as a major and efficient tool as these areas are characterized by hilly topography and harsh environment. This makes the conventional field survey difficult if not impossible. Remote sensing results obtained in this study have emphasized the viability of remote sensing technique in geological mapping and mineral exploration. Alteration zones which are normally rich in mineral deposits were successfully mapped using transformation techniques such as band ratioing and Feature Oriented Principal Components Analysis (FOPCA). The outcome of these transformations shows that the area has potential for mineral exploration and exploitation. This process revealed the existence of alteration zones within the study area.

Geochemical analysis proves the altered rocks to be gold $\mathrm{Au})$ bearing. This is in general, an encouraging result for further exploration in the outlined area, since it is known from literature that the mineralization zones in the Red Sea Hills have the same linear structures, in addition to their very existence in the acid meta-volcanic rocks as the alteration zones in the study area.

For future studies, more detailed fieldwork should be conducted especially in the outlined alteration zones to verify the remote sensing results and to collect good amounts of field measurements to enhance the geologic understanding of the area and to re-correct the final geological maps. Also, a detailed structural analysis of the lineaments of the study area should be carried out. Future research could incorporate high (spectral and spatial) resolution satellite data to map certain windows of geologic and/or target localities of economic significance in the area. This will support the production of more detailed geological maps of suitable scales.

Funding The authors received no special funding for this research.

Open Access This article is licensed under a Creative Commons Attribution 4.0 International License, which permits use, sharing, adaptation, distribution and reproduction in any medium or format, as long as you give appropriate credit to the original author(s) and the source, provide a link to the Creative Commons licence, and indicate if changes were made. The images or other third party material in this article are included in the article's Creative Commons licence, unless indicated otherwise in a credit line to the material. If material is not included in the article's Creative Commons licence and your intended use is not permitted by statutory regulation or exceeds the permitted use, you will need to obtain permission directly from the copyright holder. To view a copy of this licence, visit http://creativecommons.org/licenses/by/4.0/.

\section{References}

Abrams MJ (1984) Landsat 4, thematic mapper and thematic mapper simulator data for a porphyry copper deposit. Photogramm Eng Remote Sens 50:1171-1173

Afify HA (2011) Evaluation of change detection techniques for monitoring land-cover changes: a case study in New Burg ElArab area. Alex Eng J 50(2):187-195. https://doi.org/10.1016/j. aej.2011.06.001

Ali EA, El Khidir SO, Babikir IAA, Abdelrahaman EM (2012) Landsat $\mathrm{ETM}+$ digital image processing for lithological and structural enhancement, Abediya Area. North Sudan Open Remote Sens J 5:83-89

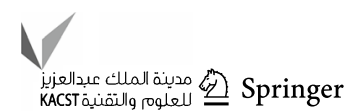


Amer R, Kusky T, El Mezayen A (2012) Remote sensing detection of gold related alteration zones of Um Rus Area, central eastern desert of Egypt. Adv Space Res 49:121-134

Aminzadeh B, Samani F (2006) Identifying the boundaries of the historical site of persepolis using remote sensing. Remote Sens Environ 102:52-62

Azizi H, Tarverdi MA, Akbarpour A (2010) Extraction of hydrothermal alterations from ASTER SWIR data from east Zanjan. North Iran Adv Space Res 46:99-109

Crippen RE, Blom RG (2001) Unveiling the lithology of vegetated terrains in remotely sensed imagery. Photogramm Eng Remote Sens 67(8):935-946

Crosta AP, McMoore J (1989) Enhancement of landsat thematic Mapper imagery for residual soil mapping in SW Minais Gerais State, Brasil: a prospective case history in green stone belt terrain. In: Proceedings of the 7th (ERIM) Thematic Conference-Remote Sensing for Exploration Geology, Calgary, 1989, pp 1173-1187

Drury SA (1987) Image interpretation in geology, 2nd edn. Chapman \& Hall, London. https://doi.org/10.1007/978-94-010-9393-4

Drury SA (1993) Image interpretation in geology, 3rd edn. Chapman \& Hall, London

Elsayed Zeinelabdein KA, Albiely AI (2008) Ratio image processing techniques: a prospecting tool for mineral deposits, Red Sea Hills, NE Sudan. Int Arch Photogram Remote Sens Spat Inf Sci $37: 1295-1297$

Elsayed Zeinelabdein KA (2010) Sudan experience in using remote sensing for mineral prospecting. In: Proceedings of the 11th Arab Conference for Mineral Resources, Arab Industrial Development and Mining Organization, Tripoli, Great Jamahiriya. p 636-644

Elsayed Zeinelabdein KA, El Nadi AH (2014) The use of landsat 8 OLI image for the delineation of gossanic ridges in the Red Sea Hills of NE Sudan. Am J Earth Sci 1(3):62-67

El Zalaky MA, Essam ME, El Arefy RA (2018) Assessment of band ratios and feature-oriented principal component selection (FPCS) techniques for iron oxides mapping with relation to radioactivity using landsat 8 at Bahariya Oasis. Egypt Res 10(4):1-10. https:// doi.org/10.7537/marsrsj100418.01

Elsayed Zeinelabdein KA, El-Nadi AHH, Babiker IS (2020) Prospecting for gold mineralization with the use of remote sensing and GIS technology in North Kordofan State, central Sudan. Sci Afr 10:e00627

Estes JE (1983) Manual of remote sensing, 2nd edition-volume II. Interpretation and application. Pub. by American society of Photogrammetry-the Sheridan Press, USA

Farina P, Catani F, Colombo D, Fumagalli A, Kukavicic M, Marks F, Moretti S (2005) Remote sensing: a tool for landslide investigations at a basin scale. Geophys Res Abstr 7:10157-10168

Gibson PJ (2000) Introductory remote sensing principles and concepts. Routledge, London

Gupta RP (2003) Remote sensing geology, 2nd edn. Springer, Berlin

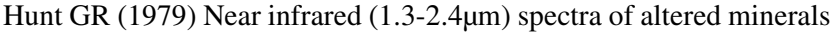
potential for use in remote sensing. Geophysics 44:1984-1986. https://doi.org/10.1190/1.1440951

Jensen JR (1996) Introductory digital image processing: a remote sensing perspective, 2nd edn. Prentice-hall Inc., New Jersey

Kenea NH (1997) Digital Enhancement of Landsat data, spectral analysis and GIS data integration for geological studies of the Derudeb area, Southern Red Sea Hills, NE Sudan. Berliner Geowiss Abh., D14, Berlin

Kruse FA, Dietz JB (1991) Integration of diverse remote sensing datasets for geologic mapping and resource exploration. In: Proceeding SPIE - The International Society for Optical Engineering, Earth and Atmospheric Remote Sensing 1492: 326-337

Loughlin WP (1991) Principal component analysis for alteration mapping. Photogramm Eng Remote Sens Photogramm 57(9):1163-1169
Modabberi S, Ahmadi A, Tangestani MH (2017) Sub-pixel mapping of alunite and jarosite using ASTER data: a case study from north of Semnan, north central Iran. Ore Geol Rev 80:429-436

Omer EAH, Elsayed Zeinelabdein KA (2018) Digital image processing of Landsat 8 and spectral analysis of ASTER data for mapping alteration minerals, Southern Hamisana, NE Sudan. Al Neelain J Geosci 2(1):10-20

Petrovic A, Khan SD, Thurmond AK (2012) Integrated hyperspectral remote sensing, geochemical and isotopic studies for understanding hydrocarbon-induced rock alterations. Mar Pet Geol 35:292-308

Pour BA, Hashim M (2015) Integrating PALSAR and ASTER data for mineral deposits exploration in tropical environments: a case study from Central Belt, Peninsular Malaysia. Int J Image Data Fusion 6(2): 170-188

Pournamdary M, Hashim M, Pour BA (2014) Application of ASTER and landsat TM data for geological mapping of Esfandagheh ophiolite complex. South Iran Resour Geol 64(3):233-246

Podwysocki MH, Segal DB, Abrams MJ (1983) Use of multispectral Scanner images for assessment of hydrothermal alteration in the Marysvale, Utah Mining Area. Econ Geol 78:675-687

Prost G (1980) Alteration mapping with airborne multispectral scanners. Econ Geol 75:894-906. https://doi.org/10.2113/gseco ngeo.75.6.894

Rajendran S, Al-Khirbasha S, Pracejusa B, Nasira S, Al-Abria AH, Kusky TM, Ghulam A (2012) ASTER detection of chromite bearing mineralized zones in Semail Ophiolite Massifs of the northern Oman mountains: exploration strategy. Ore Geol Rev 44:121-135

Roberson Research International (1985) Recent mineral discoveries in the Red Sea Hills, Sudan. Unpublished report

Rowan LC, Kahle AB (1982) Evaluations of 0.46-2.36 micrometer Multispectral scanners images of the East Tintic mining district, Utah, for mapping hydrothermally altered rocks. Econ Geol $77: 441-452$

Sabins FF (1997) Remote sensing: principles and interpretation, 3rd edn. W.H.Freeman and Company, New York

Sabins FF (2000) Remote sensing: principles and interpretation, 3rd edn. W.H.Freeman and Company, New York

Safari M, Maghsodi A, Pour AB (2017) Application of Landsat-8 and ASTER satellite remote sensing data for porphyry copper exploration: a case study from Shahr-e-Babak, Kerman, south of Iran. Geocarto Int 32:1-16

Segal DB (1983) Use of Landsat multispectral scanner data for definition of Limonitic exposures in heavily vegetated areas. Econ Geol 78:711-722. https://doi.org/10.2113/gsecongeo.78.4.711

Singh A (1989) Digital change detection techniques using remotely sensed data. Int J Remote Sens 10:989-1003

Sultan M, Arvidson RE, Sturchio RC, Guinness EA (1987) Lithologic mapping in arid regions with Landsat thematic mapper data: meatiq dome, Egypt. Geol Soc Am Bull 99(6):748-762

Van Ruitenbeek FJA, Cudahy TJ, Van der Meer FD, Hale M (2012) Characterization of the hydrothermal systems associated with Archean VMS-mineralization at Panorama, Western Australia, using hyperspectral, geochemical and geothermometric data. Ore Geol Rev 45:33-46

Yousif MSM, Shedid GA (1999) Remote sensing signature of some selected basement rock units from the central eastern desert of Egypt. Egypt J Remote Sens Space Sci 1:132-141

Publisher's Note Springer Nature remains neutral with regard to jurisdictional claims in published maps and institutional affiliations. 